\title{
Tanggung Jawab Pemuda terhadap Masa Depan Pancasila
}

\author{
Despan Heryansyah \\ Pascasarjana Hukum UII Yogyakarta \\ Jl. Cik Di Tiro No. 1 Yogyakarta \\ despan.her@gmail.com
}

\begin{abstract}
Pancasila has not provided a great influence on the development of Indonesia. This is caused by the history of the implementation of Pancasila which is laden with irregularities committed by the authorities. The problem in this study is, first, how is the responsibility of the youth to the future of Pancasila? Second, what are the values contained in Pancasila. This research is doctrinal. Legal materials used in the form of primary and secondary legal materials. The method used the philosophical approach and historical approach. The finding of this study concluded that, first, youth personal responsibility is to continue the improvement of the character by studying and implementing the values of Pancasila. Secondly, Pancasila containing the noble values of divinity, humanity, unity, democracy, and justice must be instilled as early as possible within Indonesian society.
\end{abstract}

Keywords: Youth, Pancasila, noble values, reform

\begin{abstract}
Abstrak
Pancasila belum memberikan pengaruh yang besar terhadap perkembangan bangsa Indonesia. Hal ini disebabkan oleh sejarah pengimplementasian Pancasila yang sarat dengan penyimpanganpenyimpangan yang dilakukan oleh penguasa. Permasalahan dalam penelitian ini adalah, pertama, bagaimana tanggung jawab pemuda terhadap masa depan Pancasila? Kedua, nilai-nilai apa yang terkandung dalam Pancasila. Penelitian ini merupakan penelitian doktrinal. Bahan hukum yang digunakan berupa bahan hukum primer dan sekunder. Metode pendekatan yang digunakan yakni pendekatan filosofis dan pendekatan historis. Hasil penelitian, menyimpulkan bahwa, pertama, tanggung jawab pemuda secara pribadi adalah terus memperbaiki karakter diri dengan mempelajari dan mengimplementasikan nilai-nilai dalam Pancasila. Kedua, Pancasila mengandung nilai-nilai luhur ketuhanan, kemanusiaan, persatuan, kerakyatan, dan keadilan yang harus ditanamkan sedini mungkin dalam diri masyarakat Indonesia.
\end{abstract}

Kata kunci: Pemuda, Pancasila, nilai luhur, reformasi 


\section{Pendahuluan}

Dalam sejarah perjuangan semua bangsa di dunia, pemuda tidak pernah absen untuk ambil bagian. Semangat membara dan idealisme yang masih dijunjung tinggi adalah komponen primer yang menjadi senjata utama pergerakan pemuda. Meski cenderung terkesan anarki, namun peran serta pemuda dalam setiap momen tak dapat dilupakan begitu saja. Anarki adalah bagian dari jiwa muda yang masih berkobar, bukan karena pesanan atasan dengan tawaran materi atau jabatan seperti halnya yang banyak dilakukan oleh selain pemuda.

Indonesia memang merdeka pada tahun 19451, namun gerakan para pemuda (untuk memperjuangkan kemerdekaan) sudah dimulai jauh sebelum itu. Perjuangan yang terorganisir diawali dengan lahirnya Budi Utomo pada tahun 1908, organisasi ini berusaha memunculkan kesadaran bahwa kemerdekaan tidak hanya bisa dicapai dengan kekuatan otak melainkan juga dengan kecerdasan akal. Pasca Budi Utomo banyak organisasi kepemudaan lain yang bermunculan untuk tujuan yang sama, yaitu mencapai kemerdekaan Indonesia, hingga pada puncaknya meletuslah apa yang kita peringati setiap tanggal 28 Oktober, yaitu Sumpah Pemuda tanggal 28 Oktober 1928 yang di pelopori oleh pemuda-pemudi Indonesia. ${ }^{2}$ Kalau kita hayati lebih mendalam, sumpah pemuda ini merupakan aktivitas yang melampaui rasionalitas zamannya, yang hanya bisa dilakukan oleh orang-orang yang memiliki kesadaran tinggi akan satu-kesatuan dan persamaan nasib sebagai sebuah bangsa. Bisa kita bayangkan, sumpah para pemuda yang dilakukan untuk mengikatkan diri sebagai satu-kesatuan ditengah jajahan negara kolonial kejam yang menginginkan imprealisme tanpa batas. Bagaimanapun, sumpah pemuda tahun 1928 patut mendapat tempat tersendiri di hati para pemuda sebagai suatu simbol bahwa perjuangan memang membutuhkan keberanian dan idealisme.

1 Ada sebagian pendapat yang menyataka bahwa secara de jure bahwa Indonesia merdeka adalah pada tahun 1949, setelah Belanda mengakui adanya kemerdekaan itu melalui perjanjian di Den Haag, Belanda. Pendapat ini tidaklah benar, karena baik secara de facto ataupun de jure Indonesia merdeka pada tanggal 17 Agustus 1945.

${ }^{2}$ Isi dari Sumpah Pemuda ini adalah : Kami putra-putri Indonesia mengaku, berbangsa satu bangsa Indonesia, berbahasa satu bahasa Indonesia, dan bertumpah darah satu tanah air Indonesia. 
Tahun 1945 saat kemerdekaan, tak ada yang mengingkari bagaimana peran pemuda dalam keikut sertaannya sebelum proklamasi kemerdekaan. Merasa bujukan dan lobinya terhadap Soekarno-Hatta tidak akan berhasil, para pemuda terpaksa harus "menculik" kedua tokoh ini lalu di asingkan ke Rengas Dengklok. ${ }^{3}$ Ada dua kekuatan yang tarik-menarik ketika itu, yaitu golongan tua dengan kematangan emosional dan pengalamannya yang menginginkan proklamasi kemerdekaan Indonesia dilakukan sesuai dengan keinginan Jepang. ${ }^{4}$ Di sisi lain ada golongan muda dengan jiwa dan semangatnya yang radikal menginginkan agar proklamasi kemerdekaan Indonesia dilaksanakan secepatnya, ${ }^{5}$ tanpa harus menunggu keputusan dari pemerintah Jepang, karena menurut mereka Jepang saat itu telah hancur serta agar kemerdekaan Indonesia tidak terkesan atas pemberian Jepang melainkan atas perjuangan rakyat Indonesia sendiri. Kompromi atas kedua golongan ini akhirnya disepakati dalam proklamasi kemerdekaan Indonesia yang dilaksanakan pada tanggal 17 Agustus 1945, dengan berbagai macam pertimbangan baik agama, politik, maupun sosial.

Begitu pula pada reformasi tahun 1998, meski pemuda tak banyak terlibat dalam mengkonsep rumusan Indonesia baru melalui regulasi, namun bisa dikatakan tanpa gerakan pemuda yang dipelopori oleh mahasiswa, Soeharto tidak akan rela melepaskan jabatannya. Mengenang pengorbanan yang telah dilakukan oleh pemuda sejak sebelum Indonesia merdeka, dengan baju idealisme dan keberaniannya telah banyak hal yang ditorehkan oleh para pemuda. Namun, tidak jarang perjuangan itu harus dengan mengorbankan jiwa. Tidak sedikit pemuda yang meninggal dalam medan perjuangan, bahkan perjuangan bukan dengan penjajah asing, sebagian mereka menghembuskan nafas terakhir karena kekejaman pemerintahan Indonesia sendiri.

Bagaimana peran pemuda dalam menjaga idealisme dan memperjuangkan kebenaran ini, tidak hanya kita kenal di negara Indonesia saja, dalam agama pun dikisahkan bagaimana Ibrahim melawan kesesatan kaumnya hingga harus

\footnotetext{
${ }^{3}$ Dalam catatan sejarah yang sampai kepada kita, para pemuda mengasingkan Soekarno-Hatta ke Rengas Dengklok karena khawatir kedua tokoh ini akan dipengaruhi oleh orang-orang Jepang. Sehingga keinginan mereka untuk segera memproklamasikan kemerdekaan Indonesia akan tertunda.

${ }^{4}$ Jepang telah berjanji kepada Indonesia akan memberikan kemerdekaan.

${ }_{5}^{5}$ Golongan muda menginginkan kemerdekaan Indonesia dilaksanakan pada tanggal 15 atau16 Agustus 1945, namun tidak disetujui oleh Soekarno dan golongan tua.
} 
dibakar hidup-hidup, bagaimana Musa melawan kekejaman raja Fir'aun dan bagaimana Muhammad saw yang begitu gusar dan sering menyendiri memikirkan kaumnya yang hidup dengan kesesatan. ${ }^{6}$

Tulisan di atas adalah untuk memberikan gambaran tentang bagaimana pemuda memberikan kiprahnya di setiap jaman. Pemuda sangat dibutuhkan perannya dalam mengawal perjalanan bangsa, baik sebagai pemberi kontrol atau pemberi masukan dalam rangka untuk menentukan kebijakan pemerintah. Namun lebih dari itu semua, pemuda adalah generasi penerus bangsa yang akan mengisi semua pos-pos pemerintahan berikutnya. Pemuda adalah calon pemimpin masa depan yang telah disiapkan masanya tersendiri kelak untuk menjadi pemimpin. Pemimpin yang akan memegang tumpuk pemerintahan dimana nasib rakyat dan negara digantungkan di atas pundaknya. Dengan tanggung jawab yang begitu besar, maka seorang pemuda selain dituntut memiliki kecerdasan intelektual dan kemampuan manajemen yang baik, juga harus memiliki moral serta akhlak yang juga baik. Pemuda yang memahami cita dasar (rechtsidee), filsafat hidup, pandangan hidup serta ideologi negara saat di didirikan, agar kelak saat benar-benar menjadi pemimpin negara, segala aktivitas yang dilakukan tidak menyimpang dari apa yang telah dirumuskan oleh founding fathers ${ }^{7}$.

Realitas yang yang kita saksikan pada saat ini, bisa dikatakan berbanding terbalik dengan hal di atas. Akhir-akhir ini ada beberapa pemuda yang karir politiknya melonjak pesat, namun kandas di tengah jalan karena tersandung kasus korupsi. Di sisi lain, kondisi sistem bernegara di Indonesia juga belum sepenuhnya lepas dari pengaruh orde baru, karena meskipun reformasi telah merubah banyak hal, namun orang-orang yang duduk di birokrasi termasuk beberapa pejabat penting negara masih merupakan orang-orang "peninggalan" Orde Baru. Dalam artian penyimpangan-penyimpangan yang terjadi pada masa

\footnotetext{
${ }^{6}$ Kesesatan yang terjadi pada masa Jahiliyah yang telah membuat kehidupan masyarakat menjadi kacau dan tidak terkendali, barangkali sama dengan korupsi dan kejahatan lain yang terjadi pada masa modern sekarang ini. Artinya perjuangan untuk menjadi "Muhammad" yang berikutnya masih tetap dibutuhkan (bukan sebagai nabi tetapi sebagai orang yang gusar dan sedih dengan moral rakyatnya).

${ }^{7}$ Menurut Mahfud MD., penggunaan istilah Founding Fathers tidak tepat, karena seolah-olah meniadakan peran perempuan dalam perjuangan kemerdekaan RI, sehingga istilah yang tepat menurutnya adalah Founding People. Lihat Moh. Mahfud MD, Perdebatan Hukum Tata Negara Pascaamandemen Konstitusi, Rajawali Pers, Jakarta, 2010, hlm. XII.
} 
Orde Baru masih besar kemungkinannya untuk kembali pada masa kini. Oleh karena itu, sebagai generasi penerus bangsa, pemuda harus dibekali oleh integritas terlebih dahulu, agar saat kesempatan untuk menjadi pemimpin bangsa diberikan kepadanya, penyelewengan dan penyalahgunaan wewenang seperti yang ditakutkan tidak dilakukannya.

Salah satu upaya yang bisa dilakukan untuk membentuk integritas para pemuda adalah dengan kembali menanamkan nilai-nilai pancasila dan pembukaan UUD 1945, agar nilai-nilai itu mengkristal menjadi karakter dan kepribadian setiap pemuda sehingga dalam segala aktifitasnya terutama dalam menjalankan tugas dan tanggung jawab terhadap negara dijiwai oleh nilai-nilai Pancasila dan pembukaan UUD 1945. Apa tanggung jawab dan nilai-nilai apa yang bisa diambil oleh pemuda dari Pancasila dan pembukaan UUD 1945 serta bagaimana mengimplementasikan nilai-nilai tersebut merupakan kajian utama dalam penelitian ini.

\section{Rumusan Masalah}

Permasalahan dalam penelitian ini adalah, pertama, bagaimana tanggung jawab pemuda terhadap masa depan Pancasila? Kedua, nilai-nilai apa yang terkandung dalam Pancasila?

\section{Tujuan Penelitian}

Tujuan penelitian ini adalah, pertama, untuk mengetahui tanggung jawab pemuda terhadap masa depan Pancasila. Kedua, menggali nilai-nilai yang terkandung dalam Pancasila.

\section{Metode Penelitian}

Penelitian ini merupakan penelitian hukum doktrinal. Bahan hukum yang digunakan berupa bahan hukum primer dan sekunder. Metode pendekatan yang 
digunakan yakni pendekatan filosofis dan pendekatan historis. Bahan hukum yang sudah ada itu kemudian dianalisis secara deskriptif kualitatif.

\section{Hasil Penelitian dan Pembahasan}

\section{Orde Baru Puncak Eupimisme Makna}

Salah satu hal yang paling diingat dari Orde Baru adalah Presiden H.M. Soeharto telah melanggengkan kekuasaan dan mengokohkan otoritarianismenya secara konstitusional. Dalam artian, dengan berbagai macam upaya Orde Baru menjadikan pemerintahannya tidak bertentangan dengan konstitusi, meskipun ada banyak sekali pelanggaran-pelanggaran yang mereka lakukan. Dengan kekuasaannya yang begitu besar dan terpusat, penguasa Orde Baru selalu melakukan monopoli interpretasi (hegemony of meaning) atau mendominasi seluruh wacana kenegaraan baik dalam bidang hukum, ekonomi ataupun politik. Kekuasaan presiden menjadi sangat besar, jauh melebihi kekuasaan yang dimiliki legislatif dan yudikatif. Berdasarkan Pasal 5 UUD 1945,8 Soeharto juga memfungsikan diri secara efektif sebagai pemegang kekuasaan membentuk undang-undang, yang dalam praktik justru merupakan kekuatan utama yang mengatasi kewenangan DPR. ${ }^{9}$

Menarik bahwa tiga puluh dua tahun lamanya, rakyat betah dengan penguasa yang bertipe seperti Soeharto. Yang dapat dipastikan, Soeharto bukan saja menciptakan jumlah pendukung yang sebanyak-banyaknya, melainkan juga menyusun aturan hukum yang dapat membuat kekuasaannya tetap bertahan lama tanpa ada satupun yang mengontrolnya. Setiap ornamen kekuasaan yang dibentuknya, pasti akan selalu setia, loyal, dan patuh terhadap semua "firmannya". Ornamen itu kebal pada kritik, kebal pada nurani dan sengaja tidak menggunakan hati. Di luaran, ornamen itu tampak akan berwajah bengis, kejam dan memakan apapun yang tidak sepaham dengan keinginan Soeharto. ${ }^{10}$

\footnotetext{
${ }^{8}$ Pasal 5 UUD 1945 sebelum amandemen, Presiden memegang kekuasaan membentuk undang-undang dengan persetujuan Dewan Perwakilan Rakyat.

${ }^{9}$ Suparman Marzuki, Politik Hukum Hak Asasi Manusia, Erlangga,Jakarta, 2014, hlm. 50.

${ }_{10}$ Moh. Mahfud MD, dkk (editor), Kritik Sosial dalam Wacana Pembangunan, Cetakan Kedua, UII Press, Yogyakarta, 1999, hlm. XII.
} 
Selain Gramsci, adalah Louis Althusser, yang menyatakan bahwa bertahannya kekuasaan lebih karena relasi antara Aparat Negara Represif (wujudnya adalah presiden, menteri, TNI, lembaga kehakiman, dll) dengan Aparat Negara Ideologis (yaitu lembaga keagamaan, pendidikan, kesenian, lembaga swadaya masyarakat, media massa, dll). Pada kelompok pertama, bertahan dengan cara-cara represif, sedangkan di kelompok ke dua, bertahan dengan cetusan-cetusan ide. Melalui pendekatan psikoanalisis Althusser melihat taktik bujukan dari kekuasaan kepada rakyat, melalui pemanfaatan bahasa.

Lewat bahasa kekuasaan melakukan dominasinya dengan menciptakan mana yang dianggap benar dan mana pula yang dikategorikan melanggar. Bahasa selain dimanfaatkan untuk menguasai juga dipakai untuk sarana kontrol. Di zaman Orde Baru, banyak contoh yang bisa dipakai bagaimana Soeharto, yang punya hak untuk memberikan tafsir mengenai kebebasan. Istilah, bebas tapi bertanggung jawab, stabilitas yang dinamis, adalah contoh ringkas kuatnya kontrol bahasa. Bersamaan dengan dominasi, dilakukan pula kegiatan penciptaan struktur kekuasaan yang menyebar kemana-mana. Sama seperti yang disebut Foucault dalam karyanya yang tersohor History of Sexuality, yang mengatakan bahwa kekuasaan tidak saja berada dalam putaran presiden, menteri, militer, melainkan juga dalam keluarga, dalam rumah, atau bahkan di lapangan sepak bola sekalipun. Pada zaman Orde Baru, membuat anak pun jumlahnya dibatasi, untuk mengecat rumah pun ditentukan warnanya, bahkan tugas seorang perempuan dibuatkan aturan perundang-undangan. ${ }^{11}$

Persis seperti kekuasaan Hitler, ketika orang dipenggal kepalanya hanya karena ingin menjeritkan keluhan. Dalam kalimat Foucault, kekuasaan memang tidak dilanggengkan dengan cara kekerasan saja, tetapi juga pengetahuan dan kesenangan, dengan demikian akan tampak betapa kekuasaan akan selalu berikhtiar untuk mempengaruhi publik melalui apa yang disebut sebagai pembudayaan kepatuhan. Selama Orde Baru, bahkan di era reformasi, pendidikan tidak ubahnya seperti proses untuk membuat anak patuh, melalui pengenalan sejarah yang resmi, diajarkan pada anak didik, mana saja unsur yang dinamai pembangkangan pada negara dan mana pula pekerjaan yang dihargai 
sebagai kepatuhan. Di sanalah bekerjanya proses pengetahuan yang dilanjutkan juga lewat pembiakan mata pelajaran-mata pelajaran yang selalu beri'tikad untuk terhadap kekuasaan. Tidak pernah ada celah untuk menyuarakan protes apalagi kritikan.

Tindakan ini telah mengekang kebebasan berfikir dan berekspresi dari masyarakat termasuk pemuda, sehingga apa yang benar pada masa ini adalah apa yang direstui oleh pemerintah Orba. Termasuk dalam hal menafsirkan Pancasila. Pancasila sebagai dasar filsafat negara yang digali langsung dari nilainilai yang hidup dalam masyarakat Indonesia, sejatinya menjadi titik tolak dalam rangka mencapai kesejahteraan sosial. Namun, dalam perjalanan sejarah eksistensi Pancasila sebagai dasar filsafat negara Republik Indonesia mengalami berbagai macam interpretasi dan manipulasi politik sesuai dengan kepentingan penguasa demi kokoh dan tegaknya kekuasaan yang berlindung di balik legitimasi ideologi Pancasila. Dengan lain perkataan, dalam kedudukan seperti ini Pancasila tidak lagi diletakkan sebagai dasar filsafat serta pandangan hidup bangsa dan negara Indonesia, melainkan direduksi, dibatasi, dan dimanipulasi demi kepentingan politik penguasa pada saat itu. ${ }^{12}$

Berdasarkan kenyataan tersebut di atas, gerakan reformasi berupaya untuk mengembalikan kedudukan dan fungsi Pancasila, yaitu sebagai dasar negara Republik Indonesia, yang dalam hal ini direalisasikan melalui Ketetapan Sidang Istimewa MPR Tahun 1998 No. XVIII/MPR/1998, disertai dengan pencabutan P-4 dan sekaligus juga pencabutan Pancasila sebagai satu-satunya asas bagi Orsospol di Indonesia. Ketetapan tersebut juga sekaligus mencabut mandat MPR kepada presiden atas kewenangannya untuk membudayakan Pancasila melalui P-4 dan asas tunggal Pancasila. Monopoli Pancasila demi kepentingan penguasa inilah yang harus segera diakhiri, kemudian dunia pendidikan tinggi memiliki tugas untuk mengkaji dan memberikan pengetahuan kepada semua mahasiswa untuk benar-benar mampu memahami Pancasila secara ilmiah dan objektif.

Dampak yang cukup serius atas manipulasi Pancasila oleh para penguasa pada masa lampau, dewasa ini banyak kalangan elit politik serta sebagian masyarakat beranggapan bahwa Pancasila merupakan label politik Orde Baru.

${ }^{12}$ Kaelan, Pendidikan Pancasila, Edisi Kedelapan, Paradigma Offset, Yogyakarta, 2004, hlm. 10. 
Sehingga mengembangkan serta mengkaji Pancasila dianggap akan mengembalikan kewibawaan Orde Baru. Pandangan yang sinis serta upaya melemahkan peranan ideologi Pancasila pada era reformasi dewasa ini, akan sangat berakibat fatal bagi bangsa Indonesia, yaitu melemahnya kepercayaan rakyat terhadap ideologi negara, yang kemudian pada gilirannya akan mengancam persatuan dan kesatuan bangsa Indonesia yang telah lama dibina, dipelihara, serta didambakan bangsa Indonesia sejak dahulu. ${ }^{13}$

Bukti yang secara objektif dapat disaksikan adalah terhadap hasil reformasi yang telah empat tahun berjalan, belum menampakkan hasil yang dapat dinikmati oleh rakyat, nasionalisme bangsa rapuh, sehingga martabat bangsa Indonesia dipandang rendah di mata masyarakat internasional.

Berdasarkan alasan serta kenyataan objektif tersebut di atas, maka sudah menjadi tanggung jawab kita bersama sebagai warga negara untuk mengembangkan serta mengkaji Pancasila sebagai suatu hasil karya besar bangsa kita, yang setingkat dengan paham atau isme-isme besar dunia dewasa ini, seperti misalnya liberalisme, sosialisme, dan komunisme. Upaya untuk mempelajari serta mengkaji Pancasila tersebut terutama dalam kaitannya dengan tugas besar bangsa Indonesia untuk mengembalikan tatanan negara yang porak poranda dewasa ini. Reformasi ke arah terwujudnya masyarakat dan bangsa yang sejahtera tidak cukup hanya dengan mengembangkan dan membesarkan kebencian, mengobarkan sikap dan kondisi konflik antar elit politik, melainkan dengan segala kemampuan intelektual serta sikap moral yang arif demi perdamaian dan kesejahteraan bangsa dan negara, sebagaimana yang telah diteladankan oleh para pendiri bangsa terdahulu.

Jikalau jujur, sebenarnya dewasa ini banyak tokoh serta elit politik yang kurang memahami filsafat hidup serta pandangan hidup bangsa kita, namun bersikap seakan-akan memahaminya. Akibatnya dalam proses reformasi dewasa ini diartikan kebebasan memilih ideologi, kemudian pemikiran apapun yang dipandang menguntungkan demi kekuasaan dan kedudukan dipaksakan untuk diadopsi dalam sistem kenegaraan Indonesia. Misalnya seperti kebebasan pada masa reformasi dewasa ini yang jelas-jelas tidak sesuai dengan nilai-nilai yang 
dimiliki, dipaksakan pada rakyat sehingga akibatnya dapat dilihat berbagai macam gerakan massa secara brutal tanpa mengindahkan kaidah-kaidah hukum yang berlaku, melakukan aksinya menjarah, merusak, menganiaya bahkan menteror nampaknya dianggap sah-sah saja. Negara melalui aparat keamanan tidak mampu berbuat banyak, karena akan berhadapan dengan penegak HAM yang mendapat dukungan dunia internasional. ${ }^{14}$

Begitulah dinamika yang terjadi dari masa Orde Baru hingga sekarang, karena tindakan Orde Baru yang telah menjadikan Pancasila sebagai tameng dan legalitas kekuasaannya, memunculkan sikap sinis sebagian masyarakat terhadap Pancasila. Tugas berat yang membentang saat ini adalah mengembalikan eksistensi Pancasila agar benar-benar menjadi pandangan hidup dan filsafat hidup bangsa Indonesia.

\section{Pancasila Sebagai Philosofische Grondslag}

Belakangan ini terlihat semakin marak gerakan yang ingin menjadikan negara Indonesia menjadi negara Islam. Pancasila dianggap bertentangan dengan agama Islam, ${ }^{15}$ oleh karena itu, dasar negara harus diganti dengan Islam. Hal ini disuarakan oleh beberapa organisasi garis keras Islam, dan jumlahnya masih minoritas. Namun, jika dibiarkan jumlah mereka akan terus bertambah dan tidak menutup kemungkinan akan membahayakan keutuhan NKRI. Perdebatan mengenai hal ini sebenarnya sudah terjadi sejak masa BPUPKI, namun pada akhirnya yang disepakati adalah tetap Pancasila sebagai dasar negara. Pancasila telah teruji keampuhannya di dalam berbagai ujian berat sejarah negeri ini, Pancasila telah terbukti merupakan fundamen yang kokoh dan kuat bagi tegaknya bangunan negara Republik Indonesia. ${ }^{16}$

${ }^{14}$ Ibid.

15 Pertentangan ini juga sebenarnya terjadi dalam agama Nasrani (Khatolik dan Kristen), bahwa dalam agama Kristen ada pemisahan wewenang kenegaraan dan wewenang keagamaan dalam hal ini gereja. Setelah melalui perdebatan yang alot dan pemimpin gereja yakin dengan tetap utuhnya kedaulatan theologis mereka apabila pancasila diterapkan, barulah tercapai kesepakatan. Lihat Abdurrahman Wahid dalam Oetoyo Oesman, Alfian (Penyunting), Pancasila Sebagai Ideologi dalam Berbagai Bidang Kehidupan Bermasyarakat, Berbangsa, dan Bernegara, Cetakan Ketiga, Perum Percetakan Negara RI, Jakarta, 1993, hlm. 163-164. hlm. 4.

${ }^{16}$ Dahlan Thalib, Pancasila Yuridis Ketatanegaraan, cetakan kedua, UPP AMP YKPN,Yogyakarta, 1991, 
Tidak dapat dipungkiri bahwa selain hampir 90\% penduduk Indonesia beragama Islam, jasa umat Islam dalam memperjuangkan kemerdekaan juga sangat besar. Namun harus disadari, bahwa dalam konteks ini berbicara tentang Indonesia yang sangat multikultural, yang terdiri dari tidak hanya Islam saja melainkan ada banyak agama, suku, golongan yang haknya sama sebagai warga negara Indonesia. Keberpihakan terhadap salah satu agama tentu akan memicu kecemburuan dari agama lain, akhirnya memicu terjadinya konflik horizontal. Sebagai agama rahmatan lil'alamin tentu Islam tidak menginginkan perpecahan dan konflik itu terjadi, hal ini bersesuaian dengan kaidah, menolak mudharat lebih utama dari pada mengambil manfaat.

Selain itu, di dalam Islam sendiri juga tidak memiliki sistem kenegaraan secara baku untuk dijadikan landasan dalam bernegara. Baik al-Qur'an dan hadits, ${ }^{17}$ keduanya tidak memberikan dalil rinci mengenai negara ini, sehingga urusan negara diserahkan kepada penduduk negara masing-masing sesuai dengan kebutuhannya. Islam hanya memberikan prinsip-prinsip universal dalam bernegara, misalkan musyawarah, keadilan, persamaan, toleransi dan lain sebagainya. Prinsip-prinsip inilah yang harus dipegang teguh dalam bernegara, dalam artian cukuplah nilai-nilai Islam itu yang menjadi roh dari penyelenggaraan kehidupan berbangsa dan bernegara, tanpa harus memformalkannya menjadi dasar resmi negara.

Pada tahun 1951, PB HMI (Himpunan Mahasiswa Islam) mengirimkan surat kepada Presiden Soekarno, yang isinya antara lain, apakah Islam bertentangan dengan Pancasila, apakah Islam bertentangan dengan ideologi Pancasila? Kemudian Bung Karno menjawab dalam pidatonya, dengan mengatakan "Pancasila adalah ideologi yang terbuka bagi semua agama, silahkan orang-orang Islam bersaing agar yang duduk di parlemen mayoritas orang Islam, sehingga hukum yang akan disahkan adalah hukum yang dijiwai oleh nilai-nilai Islam"18

\footnotetext{
${ }^{17}$ Salah satu buktinya adalah tidak adanya suksesi (pergantian kepemimpinan) yang bakudi dalam Islam, sejak masa rasulullah wafat hingga ke khalifah yang empat (Abu Bakar, Umar, Utsman, dan Ali) sistem pergantian kekuasaan selalu berganti-ganti.

18 Pernyataan yang sama juga dinyatakan Soekarno dalam sidang BPUPKI, saat berpidato pada tanggal 1 Juni 1945. Lihat Muhammad Yamin, Naskah Persiapan Undang-Undang Dasar 1945, Cetakan Kedua, Penerbit, Jakarta, 1971, hlm. 74-75.
} 
Maksud dari paparan singkat ini adalah, agar mencukupkan untuk memperdebatkan Pancasila sebagai dasar negara. Masalah besar bangsa Indonesia saat ini adalah kemiskinan, pengangguran, kesehatan, bencana alam, pendidikan dan masih banyak masalah besar lain. Tidak perlu menambah masalah dengan memancing konflik horizontal yang berkepanjangan serta menguras banyak energi negara. Utamanya sebagai umat Islam, tugas khalifah di muka bumi tidak bisa ditinggalkan, tanggung jawab yang begitu besar untuk mewujudkan Indonesia yang berkesejahteraan sosial telah terbentang.

\section{Makna Pancasila sebagai Filsafat dan Pandangan Hidup Bangsa Indonesia}

Pancasila adalah filsafat negara Republik Indonesia, ${ }^{19}$ yang secara resmi disahkan oleh PPKI pada tanggal 18 Agustus 1945 dan tercantum dalam Pembukaan UUD 1945, diundangkan dalam Berita Negara Republik Indonesia Tahun II No. 7, bersama-sama dengan batang tubuh UUD 1945.20 Meskipun dalam Pembukaan dan Batang Tubuh UUD 1945 tidak terdapat kata Pancasila satupun, namun dari kalimat "...yang terbentuk dalam suatu susunan Negara Republik Indonesia yang berkedaulatan rakyat dengan berdasar kepada ...". Kata “...berdasarkan kepada..." dalam Pembukaan UUD 1945 di atas, menandakan bahwa yang dimaksud adalah Pancasila, mengingat Pancasila sendiri maknanya adalah dasar negara.

Terdapat berbagai macam pengertian kedudukan Pancasila yang masingmasing harus dipahami sesuai dengan konteksnya. Misalnya, Pancasila sebagai Pandangan Hidup Bangsa Indonesia, sebagai Dasar Filsafat Negara Republik Indonesia, sebagai Ideologi Bangsa dan Negara Indonesia dan masih banyak kedudukan dan fungsi Pancasila lainnya. Seluruh kedudukan dan fungsi Pancasila itu bukanlah berdiri secara sendiri-sendiri, namun bilamana dikelompokkan, maka akan kembali pada dua kedudukan dan fungsi Pancasila,

\footnotetext{
19 Salah satu lingkup pengertian filsafat adalah fungsinya sebagai suatu pandangan hidup suatu masyarakat atau bangsa tertentu. Harold Titus, Marilyn S. Smith, and Richard T. Noland, Living Issues Philosophy, 1984. 2002, hlm. 10

Kaelan, Filsafat Pancasila Pandangan Hidup Bangsa Indonesia, Cetakan Pertama, Paradigma,Yogyakarta,
} 
yaitu sebagai Dasar Filsafat Negara dan sebagai Pandangan Hidup Bangsa Indonesia. ${ }^{21}$

Sebelum Pancasila dirumuskan dan disahkan sebagai Dasar Filsafat Negara, nilai-nilainya telah ada pada bangsa Indonesia yang merupakan pandangan hidup, yaitu berupa nilai-nilai adat-istiadat dan kebudayaan serta sebagai kausa materialis Pancasila. Dalam pengertian inilah, maka antara Pancasila dengan bangsa Indonesia tidak dapat dipindahkan sehingga Pancasila sebagai Jati Diri Bangsa Indonesia. Setelah bangsa Indonesia mendirikan negara, maka oleh pembentuk negara Pancasila disahkan menjadi Dasar Negara Republik Indonesia. Sebagai suatu bangsa dan negara, Indonesia memiliki cita-cita yang dianggap paling sesuai dan benar, sehingga segala cita-cita, gagasan-gagasan, ideide tertuang dalam Pancasila. Maka, dalam pengertian inilah Pancasila berkedudukan sebagai ideologi bangsa dan negara Indonesia, sekaligus sebagai asas persatuan dan kesatuan bangsa dan negara Indonesia. Dengan demikian, Pancasila sebagai filsafat negara, secara objektif diangkat dari pandangan hidup yang sekaligus juga sebagai filsafat hidup bangsa Indonesia yang telah ada dalam sejarah bangsa sendiri. ${ }^{22}$

Pancasila sebagai suatu sistem filsafat, pada hakikatnya merupakan suatu nilai sehingga merupakan sumber nilai dari segala penjabaran norma baik norma hukum, norma moral maupun norma kenegaraan lainnya. Dalam filsafat Pancasila terkandung didalamnya suatu pemikiran-pemikiran yang bersifat kritis, mendasar, rasional, sistematis dan komprehensif (menyeluruh) dan sistem pemikiran ini merupakan suatu nilai. Oleh kerena itu, suatu pemikiran filsafat tidak secara langsung menyajikan norma-norma yang merupakan pedoman dalam suatu tindakan atau aspek praksis melainkan suatu nilai-nilai yang bersifat mendasar. ${ }^{23}$

Sebagai suatu nilai, Pancasila memberikan dasar-dasar yang bersifat fundamental dan universal bagi manusia baik dalam hidup bermasyarakat berbangsa dan bernegara. Adapun manakala nilai-nilai tersebut akan dijalankan dalam kehidupan yang bersifat praksis atau kehidupan yang nyata dalam masyarakat, bangsa maupun negara, maka nilai-nilai tersebut kemudian

\footnotetext{
${ }^{21}$ Kaelan, Ibid., hlm. 46.

${ }^{22}$ Ibid., hlm. 47.

${ }^{23}$ Kaelan, Pendidikan Pancasila, Op. Cit., hlm. 85.
} 
dijabarkan dalam suatu norma-norma yang jelas sehingga merupakan suatu pedoman. Norma-norma tersebut meliputi, pertama, norma moral yaitu yang berkaitan dengan tingkah laku manusiayang dapat diukur dari sudut baik maupun buruk, sopan ataupun tidak sopan, susila ataupun tidak susila. Dalam kapasistas inilah nilai-nilai Pancasila telah dijabarkan dalam suatu norma-norma moralitas atau norma-norma etika, sehingga Pancasila merupakan sistem etika dalam bermasyarakat, berbangsa dan bernegara. Kedua, norma hukum yaitu suatu sistem peraturan perundang-undangan yang berlaku di Indonesia. Dalam pengertian inilah maka Pancasila berkedudukan sebagai sumber hukum di negara Indonesia. Sebagai sumber hukum, nilai-nilai Pancasila sejak dulu telah merupakan suatu cita-cita moral yang luhur yang terwujud dalam kehidupan sehari-hari bangsa Indonesia sebelum membentuk negara.

Jadi, sila-sila Pancasila pada hakikatnya bukanlah merupakan suatu pedoman yang lansung bersifat normatif ataupun praksis, melainkan merupakan suatu sistem nilai-nilai etika yang merupakan sumber norma baik meliputi norma moral maupun norma hukum, yang pada gilirannya harus dijabarkan lebih lanjut dalam norma-norma etika, moral maupun norma hukum dalam kehidupan kenegaraan maupun kebangsaan. ${ }^{24}$

Sebagai filsafat negara serta sebagai filsafat hidup bangsa Indonesia pada hakikatnya merupakan nilai-nilai yang bersifat sistematis, fundamental, dan menyeluruh. ${ }^{25}$ Maka sila-sila Pancasila merupakan suatu kesatuan yang bulat dan utuh, hirarkis dan sistematis tidak boleh dipisahkan-pisahkan satu sama lain atau diambil sekedar sebagian daripadanya. ${ }^{26}$ Dalam pengertian inilah, maka sila-sila Pancasila merupakan suatu sistem filsafat. Konsekuensinya kelima sila bukan terpisah-pisah dan memiliki makna sendiri-sendiri melainkan memiliki esensi serta makna yang utuh. Dalam susunan hirarkis dan piramidal ini, maka Ketuhanan yang Maha Esa menjadi basis Kemanusiaan, Persatuan Indonesia, Kerakyatan, dan Keadilan Sosial. Sebaliknya, Ketuhanan Yang Maha Esa adalah

${ }^{24}$ Ibid., hlm. 86.

25 Ada juga yang berpendapat bahwa sila-sila dalam pancasila adalah terpisah satu sama lain, sehingga tiap-tiap sila bediri diri sendiri dan berkedudukan sama dengan sila yang lain, misalnya Sayuti Melik dan Sultan Takdir Alisjahbana. Lihat Deliar Noer, Islam, Pancasila dan Asas Tunggal, PT. Paradigma Press,Jakarta, 1983, hlm. 108-109.

26 Soekarno, Pancasila Sebagai Dasar Negara, Inti Idayu Press, Jakarta, 1984, hlm. 67. 
Ketuhanan yang berkemanusiaan, yang membangun, memelihara dan mengembangkan persatuan Indonesia, yang berkerakyatan dan berkeadilan sosial demikian selanjutnya sehingga tiap-tiap sila di dalamnya mengandung sila-sila lainnya. Rumusan Pancasila yang bersifat hierarkis dan berbentuk piramidal ini adalah sebagai berikut :27 1 . Sila pertama: Ketuhanan Yang Maha Esa adalah mendasari dan menjiwai sila-sila kemanusiaan yang adil dan beradab, persatuan Indonesia, kerakyatan yang dipimpin oleh hikmat kebijaksanaan dan permusyawaratan/perwakilan, keadilan sosial bagi seluruh rakyat Indonesia; 2. Sila kedua: Kemanusiaan yang adil dan beradab adalah didasari dan dijiwai oleh Ketuhanan Yang Maha Esa, adalah mendasari dan menjiwai sila-sila persatuan Indonesia, kerakyatan yang dipimpin oleh hikmat kenijaksanaan dalam permusyawaratan / perwakilan, keadilan Indonesia; 3. Sila ketiga: Persatuan Indonesia adalah didasari dan dijiwai Ketuhanan Yang Maha Esa dan kemanusiaan yang adil dan beradab, serta mendasari dan menjiwai sila kerakyatan yang dipimpin oleh hikmat kebijaksanaan dalam permusyawaratan perwakilan dan keadilan sosial bagi seluruh rakyat Indonesia; 4. Sila keempat: kerakyatan yang dipimpin oleh hikmat kebijaksanaan dalam permusyawaratan/perwakilan, adalah didasari dan dijiwai oleh Ketuhanan Yang Maha Esa, kemanusiaan yang adil dan beradab, persatuan Indonesia, serta mendasari dan menjiwai keadilan sosial bagi seluruh rakyat Indonesia; 5. Sila kelima: Keadilan sosial bagi seluruh rakyat Indonesia adalah didasari dan dijiwai oleh Ketuhanan Yang Maha Esa, kemanusiaan yang adil dan beradab, persatuan Indonesia, kerakyatan yang dipimpin oleh hikmat kebijaksanaan dalam permusyawaratan/perwakilan.

Selain dalam pengertian di atas, Bernard L. Tanya juga memberikan tafsiran gotong royong sebagai penyatu dari kelima sila tersebut.28 Dasar pemikiran filosofis yang terkandung dalam setiap sila, dijelaskan sebagai berikut. Pancasila sebagai filsafat bangsa dan negara republik Indonesia mengandung makna bahwa dalam setiap aspek kehidupan kebangsaan, kemasyarakatan, dan kenegaraan, harus berdasarkan nilai-nilai Ketuhanan, Kemanusiaan, Persatuan, Kerakyatan dan Keadilan. Pemikiran filsafat kenegaraan bertolak dari suatu

${ }^{27}$ Kaelan, Filsafat Pancasila, Op. Cit., hlm. 69.

28 Bernard L. Tanya, dkk., Pancasila Bingkai Hukum Indonesia, Cetakan Pertama, Genta Publishing, Yogyakarta, 2015, hlm. 4. 
pandangan bahwa negara adalah merupakan suatu persekutuan hidup manusia atau organisasi kemasyarakatan, yang merupakan masyarakat hukum (legal society). Adapun negara yang didirikan oleh manusia berdasarkan pada kodrat bahwa manusia sebagai warga negara sebagai persekutuan hidup adalah berkedudukan kodrat manusia sebagai mahluk Tuhan Yang Maha Esa (hakikat silsa pertama). Negara yang merupakan persekutuan hidup manusia sebagai mahluk Tuhan Yang Maha Esa, pada hakikatnya bertujuan untuk mewujudkan harkat dan martabat manusia sebagai mahluk yang berbudaya atau mahluk yang beradab (hakikat sila kedua). Untuk mewujudkan suatu negara sebagai suatu organisasi hidup manusia harus membentuk suatu ikatan sebagai suatu bangsa (hakikat sila ketiga). Terwujudnya persatuan dalam suatu negara akan melahirkan rakyat sebagai suatu bangsa yang hidup dalam suatu wilayah negara tertentu. Konsekuensinya dalam hidup kenegaraan itu haruslah mendasarkan pada nilai bahwa rakyat merupakan asal mula kekuasaan negara. Maka negara harus bersifat demokratis, hak serta kekuasaan rakyat harus dijamin baik secara individu maupun secara bersama (hakikat sila ke-empat). Untuk mewujudkan tujuan negara sebagai tujuan bersama maka dalam kehidupan kenegaraan harus mewujudkan jaminan perlindungan bagi seluruh warga Indonesia, sehingga untuk mewujudkan tujuan seluruh warganya harus dijamin berdasarkan suatu prinsip keadilan yang timbul dalam kehidupan bersama (kehidupan sosial, hakikat sila kelima). Nilai-nilai inilah yang merupakan suatu nailai dasar bagi kehidupan kenegaraan, kebangsaan dan kemasyarakatan. ${ }^{29}$

Dalam uraian berikut akan dijelaskan nilai-nilai yang terkandung dalam setiap sila, namun meskipun dijelaskan secara terpisah kesemuanya tidak dapat dilepaskan keterkaitannya dengan sila-sila lainnya. Adapun nilai-nilai yang terkandung dalam setiap sila adalah sebagai berikut:

\section{Sila Ketuhanan Yang Maha Esa}

Sila Ketuhanan Yang Maha Esa ini nilai-nilainya meliputi dan membawahi keempat sila lainnya, sila Ketuhanan menjadi poros dari sila-sila lain. ${ }^{30}$ Dalam sila Ketuhanan Yang Maha Esa terkandung nilai bahwa negara yang didirikan adalah

${ }^{29}$ Kaelan, Pendidikan Pancasila, Op. Cit., hlm. 75-76.

${ }^{30}$ Bernard L. Tanya, Op. Cit., hlm. 9. 
sebagai pengejawantahan tujuan manusia sebagai mahluk Tuhan Yang Maha Esa. Oleh karena itu, segala hal yang berkaitan dengan pelaksanaan dan penyelenggaraan negara bahkan moral negara, moral penyelenggara negara, politik negara, pemerintahan negara, hukum dan peraturan perundangundangan negara, kebebasan dan hak asasi warga negara harus dijiwai nilai-nilai Ketuhanan Yang Maha Esa. Moh. Hatta menegaskan, bahwa sila Ketuhanan yang Maha Esa merupakan dasar yang memimpin cita-cita kenegaraan kita untuk menyelenggarakan yang baik bagi masyarakat dan penyelenggara negara. ${ }^{31}$

Rumusan Ketuhanan Yang Maha Esa telah memberikan sifat yang khas kepada negara Kebangsaan Indonesia, yaitu bukan merupakan negara sekuler yang memisahkan agama dan Negara, demikian juga bukan merupakan negara agama yaitu negara yang mendasarkan atas agama tertentu. Negara kebangsaan Indonesia adalah negara yang mengakui Tuhan yang Maha Esa menurut dasar kemanusiaan yang adil dan beradab, yaitu negara kebangsaan yang memelihara budi pekerti kemanusiaan yang luhur dan memegang teguh cita-cita kemanusiaan sebagai mahluk Tuhan, dengan segala hak dan kewajibannya.

Negara tidak memaksa dan tidak memaksakan agama karena agama adalah merupakan suatu keyakinan batin yang tercermin dalam hati sanubari dan tidak dapat dipaksakan, tidak ada satu agamapun yang membenarkan untuk memaksakan kepada orang lain untuk menganutnya. Dengan perkataan lain negara menjamin kemerdekaan setiap penduduk untuk memeluk agama dan untuk beribadah menuru agama dan kepercayaan masing-masing. ${ }^{32}$

\section{Sila Kemanusiaan yang Adil dan Beradab}

Sila kemanusiaan yang adil dan beradab secara sistematis didasari dan dijiwai oleh sila Ketuhanan yang Maha Esa, serta menjiwai dan mendasari ketiga sila berikutya. Sila kemanusiaan sebagai dasar fundamental dalam kehidupan kebangsaan, kenegaraan dan keasyarakatan. Nilai kemanusiaan ini bersumber pada dasar filosofis antropologis bahwa hakikat manusia adalah susunan kodrat rohani (jiwa) dan raga, sifat kodrat individu dan makhluk sosial, kedudukan

\footnotetext{
${ }^{31}$ Mohammad Hatta, Uraian Pancasila, Mutiara, Jakarta, 1984.

32 Kaelan, Pendidikan Pancasila, Op. Cit., hlm. 133.
} 
kodrat makhluk pribadi berdiri sendiri dan sebagai makhluk Tuhan yang Maha Esa.

Dalam sila kemanusiaan terkandung nilai-nilai bahwa negara harus menjunjung tinggi harkat dan martabat manusia sebagai mahluk yang beradab. Oleh karena itu, dalam kehidupan kenegaraan terutama dalam peraturan perundang-undangan negara harus mewujudkan tercapainya tujuan ketinggian harkat dan martabat manusia, terutama hak-hak kodrat manusia sebagai hak dasar (hak asasi) harus dijamin dalam peraturan perundang-undangan negara. Kemanusiaan yang adil dan beradab adalah mengandung nilai suatu kesadaran sikap moral dan tingkah laku manusia yang didasarkan pada potensi budi nurani manusia dalam hubungannya dengan norma-norma dan kebudayaan pada umumnya baik terhadap diri sendiri, terhadap sesama manusia, maupun terhadap lingkungannya. Nilai kemanusiaan yang beradab perwujudan nilai kemanusiaan sebagai mahluk yang berbudaya, bermoral, dan beragama. 33

Nilai kemanusiaan yang adil mengandung suatu makna bahwa hakikat manusia sebagai mahluk yang berbudaya dan beradab harus berkodrat adil. Hal ini mengandung suatu pengertian bahwa hakikat manusia harus adil dalam hubungan dengan diri sendiri, adil terhadap manusia lain, adil terhadap masyarakat bangsa dan negara, adil terhadap lingkungan serta adil terhadap Tuhan Yang Maha Esa. Konsekuensinya nilai yang terkandung dalam kemanusiaan yang adil dan beradab adalah menjunjung tinggi harkat dan martabat manusia sebagai mahluk Tuhan Yang Maha Esa, menjunjung tinggi hakhak asasi manusia, menghargai atas kesamaan hak dan derajat tanpa membedabedakan suku, agama, ras, keturunan maupun status sosial. ${ }^{34}$

\section{Persatuan Indonesia}

Sila persatuan Indonesia didasari dan dijiwai oleh sila Ketuhanan yang Maha Esa dan Kemanusiaan yang adil dan beradab serta mendasari dan menjiwai dua sila di bawahnya. Dalam sila Persatuan Indonesia, terkandung nilai bahwa negara adalah sebagai penjelmaan sifat kodrat manusia monodualis yaitu sebagai mahluk individu dan mahluk sosial. Negara adalah suatu persekutuan hidup

${ }^{33}$ Ibid., hlm. 80.

${ }^{34}$ Darmodiharjo, Penjabaran Nilai-nilai Pancasila dalam Sistem Hukum Indonesia, lihat dalam Kaelan, Ibid. 
bersama di antara elemen-elemen yang membentuk negara yang berupa suku, ras, kelompok golongan maupun kelompok agama. Oleh karena itu, perbedaan adalah merupakan bawaan kodrat manusia dan juga merupakan ciri khas elemen-elemen yang membentuk negara. Konsekuensinya negara adalah beraneka ragam tetapi satu, mengikatkan diri dalam suatu persatuan yang dilukiskan dalam suatu seloka Bhinneka Tunggal Ika Perbedaan bukannya diruncingkan untuk menjadi konflik dan permusuhan, melainkan diarahkan pada suatu sintesa yang saling menguntungkan yaitu persatuan dalam kehidupan bersama untuk mewujudkan tujuan bersama. ${ }^{35}$

Nilai persatuan Indonesia didasari dan dijiwai oleh sila Ketuhanan yang Maha Esa dan Kemanusiaan yang adil dan beradab. Hal ini terkandung nilai bahwa nasionalisme Indonesia adalah nasionalisme religius. Yaitu nasionalisme yang bermoral ketuhanan yang Maha Esa, nasionalisme yang humanistik yang menjunjung tinggi harkat dan martabat manusia sebagai mahluk Tuhan. Oleh karena itu, nilai-nilai nasionalisme ini harus tercermin dalam segala aspek penyelenggaraan negara termasuk dalam era reformasi dewasa ini. Proses reformasi tanpa mendasarkan pada moral ketuhanan, kemanusiaan, dan memegang teguh persatuan dan kesatuan, maka bukan tidak mungkin akan membawa kehancuran bagi bangsa Indonesia seperti halnya telah terbukti pada bangsa lain misalnya Yugoslavia, Sri Langka dan negara lainnya.

Kekhususan tersendiri bagi bangsa Indonesia, sebagai negara yang multikultural ${ }^{36}$ persatuan adalah hal yang teramat mahal dan berarti bagi bangsa Indonesia, persatuanlah yang telah mengantarkan Indonesia merdeka, persatuan pula yang telah mempertahankan kemerdekaan Indonesia baik dari rong-rongan asing maupun ancaman dari dalam. Negara Uni Sovyet, negara adikuasa dengan kekuatan militer dan nuklir yang besar, almarhum diusianya yang ke-70 salah satu penyebabnya adalah karena tidak mampu memelihara keanekaragaman negaranya.

${ }^{35}$ Ibid., hlm. 81.

36 Ada \pm 17.400 pulau, 300 suku lebih dengan bahasa dan adat-istiadat yang berbeda-beda. Jumlah penduduk yang mencapai 240.000.000 jiwa yang tersebar di 34 provinsi dan 540 kabupaten. 
Kerakyatan yang Dipimpin oleh Hikmat Kebijaksanaan dalam Permusyawaratan/Perwakilan

Nilai yang terkandung dalam sila Kerakyatan yang Dipimpin oleh Hikmat Kebijaksanaan dalam Permusyawaratan/Perwakilan, didasari dan dijiwai oleh sila Ketuhanan yang Maha Esa, Kemanusiaan yang Adil dan Beradab dan Persatuan Indonesia, serta menjiwai dan mendasari sila keadilan sosial bagi seluruh rakyat Indonesia.

Nilai filosofis yang terkandung didalamnya adalah bahwa hakikat negara adalah sebagai penjelmaan sifat kodrat manusia sebagai mahluk individu dan mahluk sosial. Hakikat rakyat adalah sekelompok manusia sebagai mahluk Tuhan yang Maha Esa yang bersatu dan bertujuan mewujudkan harkat dan martabat manusia dalam suatu wilayah negara. Rakyat merupakan subjek pendukung pokok negara, oleh karena itu rakyat merupakan asal mula kekuasaan negara. Sehingga dalam sila kerakyatan terkandung nilai demokrasi yang secara mutlak harus dilaksanakan dalam hidup negara, maka nilai-nilai demokrasi yang terkandung dalam sila keempat adalah: pertama, adanya kebebasan yang harus disertai tanggung jawab baik terhadap masyarakat masyarakat bangsa maupun secara moral terhadap Tuhan yang Maha Esa. Kedua, menjunjung tinggi harkat dan martabat kemanusiaan. Ketiga, menjamin dan memperkokoh persatuan dan kesatuan dalam hidup bersama. Keempat, mengakui atas perbedaan Individu, kelompok, ras, suku, agama, karena perbedaan adalah merupakan suatu bawaan kodrat manusia. Kelima, mengarahkan perbedaan dalam suatu kerja sama kemanusiaan yang beradab. Keenam, menjunjung tinggi asas musyawarah sebagai moral kemanusiaan yang beradab. Ketujuh, mewujudkan dan mendasarkan suatu keadilan dalam kehidupan sosial agar tercapai tujuan bersama. ${ }^{37}$

Sila kerakyatan mengandung makna bahwa kedaulatan berada di tangan rakyat, segala kebijakan negara dijalankan dari oleh dan untuk rakyat. Rakyat menjadi elemen penting dalam negara, oleh karenanya kepentingan rakyat harus berada diatas kepentingan individu, golongan, partai politik ataupun yang lainnya. Yang perlu dicatat adalah bahwa di dalam sila kerakyatan ini tidak 
berlaku ajaran mayoritas menguasai minoritas. Suatu pikiran dan perasaan dari suatu anggota tetap dihargai dan tetap berperan dalam menyusun keputusan bersama. ${ }^{38}$ Kerakyatan berbeda dengan demokrasi liberal yang berkembang di barat, demokrasi di sana diartikan sebagai kemerdekaan individu yang bersifat mutlak. Individu dilihat benar-benar menyendiri dan dapat hidup sendiri secara mandiri. Namun, dalam kerakyatan, individu tidak bisa dilepaskan dari perannya sebagai anggota masyarakat. ${ }^{39}$

\section{Sila Keadilan Sosial Bagi Seluruh Rakyat Idonesia}

Nilai yang terkandung dalam sila keadilan sosial bagi seluruh rakyat Indonesia didasari dan dijiwai oleh sila Ketuhanan yang Maha Esa, Kemanusiaan yang Adil dan Beradab, Persatuan Indonesia, serta Kerakyatan yang dipimpin oleh hikmat kebijaksanaan dalam permusyawaratan/perwakilan. Dalam sila kelima ini terkandung nilai-nilai yang merupakan tujuan negara sebagai tujuan dalam hidup bersama. Maka, dalam sila kelima ini terkandung nilai keadilan yang harus terwujud dalam kehidupan bersama (kehidupan sosial). Keadilan tersebut didasari dan dijiwai oleh hakikat keadilan kemanusiaan yaitu keadilan dalam hubungan manusia dengan dirinya sendiri, manusia dengan manusia lain, manusia dengan masyarakat, bangsa dan negaranya serta hubungan manusia dengan Tuhannya. 40

Konsekuensinya nilai-nilai keadilan yang harus terwujud dalam hidup bersama adalah meliputi:41 a. Keadilan Distributif, yaitu suatu hubungan keadilan antara negara terhadap warganegaranya, dalam arti pihak negaralah yang wajib memenuhi keadilan dalam bentuk keadilan membagi, dalam bentuk kesejahteraan, bantuan, subsidi serta kesempatan dalam hidup bersama yang didasarkan atas hak dan kewajiban; b. Keadilan legal (keadilan bertaat), yaitu

\footnotetext{
38 Mudzakkir, Selayang Pandang Sistem Hukum Indonesia menurut H. Moh. Koesnoe, Himpunan Tulisan dalam Majalah Varia Peradilan, Jakarta, 1997, hlm. 150.

39 Bung Karno mengatakan, "demokrasi atau kedaulatan rakyat mempunyai corak nasional, satu corak kepribadian kita, satu corak yang tidak perlu sama dengan corak demokrasi yang dipergunakan oleh bangsabangsa lain sebagai alat teknis. Artinya demokrasi kita adalah demokrasi Indonesia, demokrasi yang disebutkan sebagai sila keempat itu, adalah demokrasi Indonesia yang membawa corak kepribadian bangsa Indonesia sendiri. Tidak perlu identik, artinya sama dengan demokrasi yang dijalankan oleh bangsa-bangsa lain". Lihat Soekarno, Op. Cit., hlm. 90.

${ }^{40}$ Kaelan, Pendidikan Pancasila, Op.Cit., hlm. 83

${ }^{41}$ Notonagoro, Pancasila Secara Ilmiah Populer, dikutip dari Kaelan, Pendidikan Pancasila, Ibid.
} 
suatu hubungan keadilan antara warga negara terhadap negara dan dalam pihak ini pihak wargalah yang wajib memenuhi keadilan dalam bentuk mentaati peraturan perundang-undangan yang berlaku dalam negara; c. Keadilan komutatif, yaitu suatu hubungan keadilan antara warga satu dengan lainnya secara timbal balik.

Demikian nilai-nilai yang terdapat dalam sila-sila Pancasila, namun tetap harus diingat bahwa sila-sila itu adalah satu kesatuan secara utuh dan tidak terpisah. Selain itu, sebagai etika politik dalam penyelenggaraan dan pelaksanaan negara, Pancasila menuntut agar kekuasaan dalam negara dijalankan sesuai dengan: pertama, asas legalitas (legitimasi hukum), yaitu dijalankan sesuai dengan hukum yang berlaku. Kedua, disahkan dan dijalankan secara demokratis (legitimasi demokrasi). Ketiga, dilaksanakan berdasarkan prinsip-prinsip moral atau tidak bertentangan dengannya (legitimasi moral). ${ }^{42}$ Pancasila sebagai suatu sistem filsafat memiliki tiga dasar tersebut. Dalam pelaksanaan dan penyelenggaraan negara, baik menyangkut kekuasaan kebijakan yang menyangkut publik, pembagian serta kewenangan harus berdasarkan legitimasi moral religius (sila I) serta moral kemanusiaan (sila II). ${ }^{43}$ Hal ini ditegaskan oleh Moh. Hatta tatkala mendirikan negara, bahwa negara harus berdasarkan moral ketuhanan dan moral kemanusiaan agar tidak terjerumus dalam machtsstaats, atau negara kekuasaan. ${ }^{44}$

Selain itu dalam pelaksanaan dan penyelenggaraan negara harus berdasarkan legitimasi hukum yaitu prinsip "legalitas".45 Negara Indonesia adalah negara hukum, ${ }^{46}$ hukum adalah dalam rangka untuk mewujudkan keadilan. Keadilan dalam hidup bersama (keadilan sosial) sebagaimana terkandung dalam sila $\mathrm{V}$, adalah merupakan tujuan dala kehidupan bernegara. Oleh karena itu dalam pelaksanaan dan penyelenggaraan negara, segala kebijakan, kekuasaan, kewenangan serta pembagian senantiasa harus berdasarkan atas hukum yang berlaku. Pelanggaran atas prinsip-prinsip keadilan

42 Frans Magnis Suseno, Etika Politik, Prinsip-Prinsip Moral Dasar Kenegaraan Modern, P.T. Gramedia, Jakarta, 1987, hlm. 115.

43 Sila pertama dan kedua sebagai sumber moral dalam penyelenggaraan dan pelaksanaan negara, yaitu moral ketuhanan dan moral kemanusiaan.

${ }^{44}$ Kaelan, Pendidikan Pancasila, Op. Cit., hlm. 101.

${ }^{45}$ Nullum delictum nulla poena siene praviea lege poenalli.

46 Pasal 1 Ayat 3 UUD N RI Tahun 1945. 
dalam kehidupan kenegaraan akan menimbulkan ketidak seimbangan dalam kehidupan bernegara. ${ }^{47}$

Negara adalah berasal dari rakyat dan segala kebijakan dan kekuasaan yang dilakukan senantiasa untuk rakyat (sila IV). Oleh karena itu rakyat adalah asal mula kekuasaan negara, maka segala kebijakan, kekuasaan, dan kewenangan negara harus dikembalikan kepada rakyat sebagai pendukung pokok negara. Dalam pelaksanaan politik praktis hal-hal yang menyangkut kekuasaan eksekutif, legislatif dan yudikatif, serta konsep pengambilan keputusan, pengawasan serta partisipasi harus berdasarkan legitimasi dari rakyat, atau dengan kata lain harus memiliki legitimasi demokratis. ${ }^{48}$

Prinsip-prinsip dasar etika politik itu dalam realisasi praksis pada kehidupan kenegaraan senantiasa dilaksanakan secara korelatif diantara ketiganya. ${ }^{49}$ Kebijaksanaan serta keputusan yang diambil dalam pelaksanaan kenegaraan baik menyangkut politik dalam negeri maupun luar negeri, ekonomi baik nasional maupun global, yang menyangkut rakyat, dan lainnya sekalian berdasarkan hukum yang berlaku (legitimasi hukum), harus mendapat legitimasi rakyat (legitimasi demokratis), dan juga harus berdasarkan prinsip-prinsip moralitas (legitimasi moral). Misalnya kebijaksanaan harga BBM, Tarif Dasar Listrik, tarif telefon, kebijaksanaan ekonomi mikro ataupun makro, reformasi infrastruktur politik serta kebijaksanaan politik dalam maupun luar negeri harus didasarkan atas tiga prinsip tersebut. ${ }^{50}$

Etika politik ini juga harus direalisasikan oleh setiap individu yang ikut terlibat secara konkret dalam pelaksanaan pemerintahan negara. Para pejabat eksekutif, anggota legislatif, maupun yudikatif, para pejabat negara, harus menyadari bahwa selain legitimasi hukum dan legitimasi demokratis juga harus berdasar pada legitimasi moral. Karena suatu kebijaksanaan itu sesuai dengan hukum belum tentu sesuai dengan moral. Misalnya perbaikan WC anggota DPR yang mencapai jumlah miliaran atau dana bantuan parpol hingga satu triliun jika sudah dibuatkan aturannya adalah sah (legitimasi hukum), namun mengingat

\footnotetext{
${ }^{47}$ Kaelan, Pendidikan Pancasila, Op.Cit., hlm. 102.

${ }^{48}$ Namun berbeda maknanya dengan pengertian demokrasi menurut paham liberal di Barat.

${ }^{49}$ Yaitu legitimasi moral, legitimasi hukum dan legitimasi demokratis.

${ }^{50} \mathrm{Ibid}$.
} 
kondisi rakyat yang sangat menderita seperti saat ini, hal di atas menjadi tidak layak secara moral (legitimasi moral).

Saat ini, memang peran pemuda khususnya mahasiswa belum memiliki arti penting. Namun di masa yang akan datang, pemuda adalah generasi penerus bangsa yang akan mengisi semua pos-pos pemerintahan. Oleh karena itu, teramat penting agar para pemuda terlebih dahulu memahami nilai-nilai yang terkandung dalam pancasila, sehingga kemudian dapat menghayatinya untuk menjadi karakter yang menyatu dengan kehidupan. Dengan demikian, pada saatnya nanti menjadi pemimpin bangsa ini, Pancasila benar-benar menjadi dasar pijakan dalam rangka penyelenggaraan dan pelaksanaan negara untuk mewujudkan Indonesia yang sejahtera dan Indonesia yang berkarakter. Biarkan saja, biarkan para pemimpin kita saat ini dengan kejahiliahannya, kita para pemuda terus saja memperbaiki diri, untuk menjadi manusia yang berkompetensi dan berintegritas, karena saatnya nanti Indonesia akan berada ditangan kita, di tangan para pemuda.

\section{Penutup}

Dari uraian atas permasalahan di atas, dapat disimpulkan sebagai berikut. Pertama, tanggung jawab pemuda secara pribadi adalah terus memperbaiki karakter diri dengan mempelajari dan mengimplementasikan nilai-nilai dalam Pancasila. Kedua, Pancasila mengandung nilai-nilai luhur ketuhanan, kemanusiaan, persatuan, kerakyatan, dan keadilan yang harus ditanamkan sedini mungkin dalam diri masyarakat Indonesia.

\section{Daftar Pustaka}

Hatta, Mohammad, Uraian Pancasila, Mutiara, Jakarta, 1984.

Kaelan, Pendidikan Pancasila, Edisi Kedelapan, Paradigma Offset, Yogyakarta, 2004.

----------, Filsafat Pancasila Pandangan Hidup Bangsa Indonesia, Cetakan Pertama, Paradigma, Yogyakarta, 2002. 
L. Tanya, Bernard, dkk.,Pancasila Bingkai Hukum Indonesia, Cetakan Pertama, Genta Publishing, Yogyakarta, 2015.

Magnis Suseno, Frans, Etika Politik, Prinsip-Prinsip Moral Dasar Kenegaraan Modern, P.T. Gramedia, Jakarta, 1987.

Mahfud MD, Moh., Perdebatan Hukum Tata Negara Pascaamandemen Konstitusi, Rajawali Pers, Jakarta, 2010.

, dkk., (editor), Kritik Sosial dalam Wacana Pembangunan, Cetakan Kedua, UII Press, Yogyakarta, 1999.

Marzuki, Suparman, Politik Hukum Hak Asasi Manusia, Erlangga, Jakarta, 2014.

Mudzakkir, Selayang Pandang Sistem Hukum Indonesia menurut H. Moh. Koesnoe, Himpunan Tulisan dalam Majalah Varia Peradilan, Jakarta, 1997.

Noer, Deliar, Islam, Pancasila dan Asas Tunggal, PT. Paradigma Press, Jakarta, 1983.

Yamin, Muhammad, Naskah Persiapan Undang-Undang Dasar 1945, Cetakan Kedua, Penerbit, Jakarta, 1971.

Oesman Alfian, Oetoyo (Penyunting), Pancasila sebagai Ideologi dalam Berbagai Bidang Kehidupan Bermasyarakat, Berbangsa, dan Bernegara, Cetakan ketiga, Perum Percetakan Negara RI, Jakarta, 1993.

Soekarno, Pancasila Sebagai Dasar Negara, Inti Idayu Press, Jakarta, 1984.

Thaib, Dahlan, Pancasila Yuridis Ketatanegaraan, cetakan kedua, UPP AMP YKPN, Yogyakarta, 1991. 